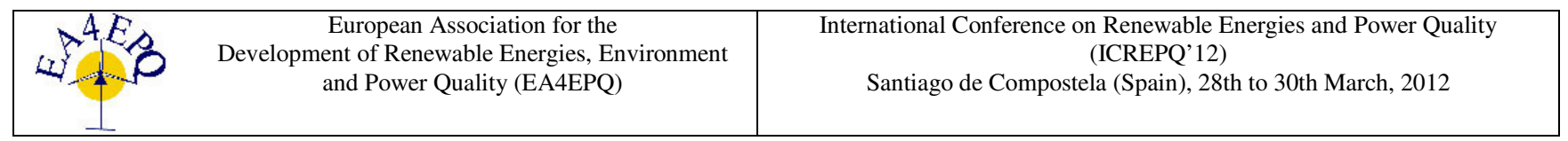

\title{
A Gasification System for the Disposal of Industrial Waste and Energy Generation: Experimentation and Thermodynamic Analysis
}

\author{
A. Gimelli ${ }^{1}$, A.Luongo $^{2}$, A.Amoresano ${ }^{1}$ \\ ${ }^{1} D I M E$ - Departmant of Mechanical and Energy, Univ. degli Studi di Napoli Federico II, gimelli@ unina.it \\ ${ }^{2}$ Faculty of Engineering, Univ. degli Studi di Napoli Federico II, alessa.luongo@studenti.unina.it
}

\begin{abstract}
.
The present paper shows the thermodynamic analysis of a gasification system (Fig. 1), which is currently used for the recovery of metals from contaminated substances of organic origin (waste of mechanical process, rolling, colddrawn, tins, multi-coupled materials, tetra, etc. .), and that, in this paper, is extended to the energy recovery and disposal of Paper Industry Waste. The interest in pyrolysis and gasification is justified because these processes go over the traditional combustion systems of biomass and waste.

In this system the inert ambient is supported by the smoke coming from the combustion of natural gas and it is possible to schematize it into a line of heat treatment and in a flue gas cleaning occurring after the combustion.

Using the results of different experimental tests a thermodynamic and thermo-chemical analysis is carried out. Starting from the energy and mass balances on the entire system and on the each component, the balance of the gasification reactions is verified.
\end{abstract}

\section{Key words}

Light Gasification and Pyrolysis, Lower Heating Value Syngas, Thermodynamic and Experimental Analysis, Renewable energy, Power Plant, Paper Industry Waste.

\section{Introduction}

Gasification, often combined with the pyrolysis (heat treatment in the absence of oxygen), has been long a variety of applications in industry, mostly in the field of chemical and petrochemical industry, for example to obtain synthesis gas from coal (known as gas-poor city) [1-3].

Currently there is a growing interest in the treatment, gasification and pyrolysis, crops, plant waste (biomass) [4] and industrial and civil waste [5], because some experiments have been undertaken on small applications to demonstrate the possibilities that this technology is a viable alternative to direct combustion waste, especially if aimed at the production of electricity and / or heat. The gasification technology is therefore consolidated using materials such as coal and oil, and today is ready to be involved in biomass waste and, in general, in organic materials like the industrial and civil waste [5]. The problems encountered in the development of this technology are related to:

$>$ optimization of process variables such as the gasifying agent, the temperature and residence time of organic material in the reactor;

$>$ the process architecture;

$>$ the study of the application in the particular field for the evaluation of any contaminants and methods of treatment and removal of the same.

$>$ the study and redesign of Power Plants working groups with low calorific gas.

For the industrial application of gasification or pyrolysis waste to so-called "undifferentiated", there are several technological proposals [6], also very different between them, which may be characterized as a function of both types of conversion equipment, which the operating conditions adopted in the full cycle of production and use of gas and any other derivative products. From the knowledge gained to date in this area, it is possible to get different results by choosing to submit to the combustion gas as obtained or after simple treatments, such as in a conventional steam generator or by using gas as fuel in equipment direct conversion, such as reciprocating engines, after gas cleaning. The second solution has a considerable potential for development because of the experience already gained in the coal and some biomass. Furthermore the production of a gaseous could be used in an Internal Combustion engine or in a gas turbine which can be adopted in a higher efficiency combined cycle. The data on the yields of conversion of this type of technology, however, are only theoretical. Many of the systems installed in a pilot scale or demonstration plant solutions often adopt a rather simple treatment and energy recovery, and also in cases involving cogeneration schemes; such systems have not been yet optimized, nor validated from the point of view of recovery energy. From a theoretical analysis it is expected a net recovery of electricity from the waste about $12-24 \%$ in the case of gasification with simple cycle, and $25-30 \%$ for the combined cycle [17]. 
This paper analyzes a gasification technology, (Fig. 1), which is currently used for the recovery of metals from contaminated substances of organic origin (waste of mechanical process, rolling, cold-drawn, tins, multicoupled materials, tetra, etc. .) extended to the energy recovery and disposal of Paper Industry Waste. The gasification Plant is experimental analyzed, measuring principal thermodynamic quantities and the syngas composition. A Thermodynamic and energetic analysis is coupled to the experimental one, to better understand the system potentiality, especially, to minimize the environmental impacts that may result from the use of synthesis gas, optimizing the energy content of the gas burner. This will be achieved by studying the specific use before and after the gasification process.

\section{Description of Gasification Plant}

A analyzed system scheme is represented in Fig. 1. It is derived from a recovery system of metals from wastes soaked with oil and paints used in metalworking. Through a campaign of experimental tests, several industrials waste has been disposed and, in particular, the Paper Industry Waste. In this paper, only experimental data of Paper Industry Waste are reported.

The heat treatment line consists of (Fig. 1) :

$>$ Storage and feeding the waste to the gassifier (1);

$>$ Production of inert gas (2);

$>$ Rotating Cylinder where is realized the gasification-pyrolysis process (3);

$>$ Discharge and cooling (4) of the solid residue (Carbon, metals, etc...);

$>$ Syngas and Tar Combustion Chamber (5);

$>$ Exhaust Flue Gas line with cleaning apparatus (6).

This plant, working in steady conditions, can treat approximately $2500 \mathrm{~kg} / \mathrm{h}$ of waste using both. The solid part of the heat treatment products is mainly composed of metals with some stable carbonaceous products.

The flue gas cleaning line consists of the following sections:

$>$ exhaust aspiration;

$>$ cleaning of exhaust;

$>$ monitoring system of emissions and operating parameters.

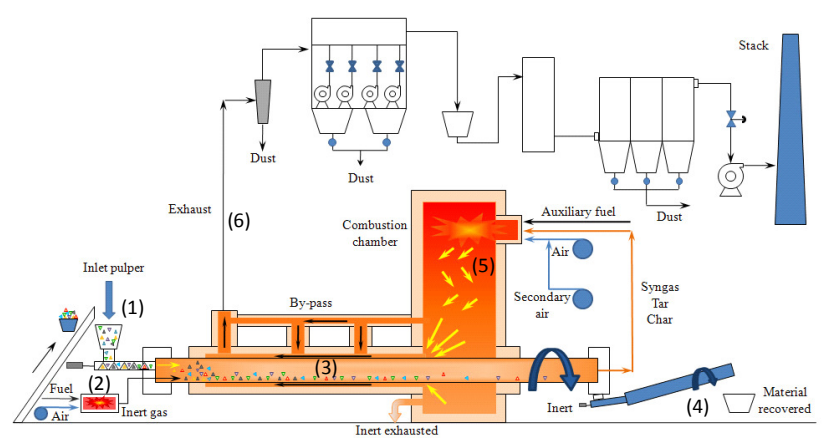

Fig. 1. Scheme of Gasification Plant

\section{Experimental analysis: supply with Paper Industry Waste}

The Paper Industry Waste is the refusal coming from pulping of waste paper bales, therefore, its composition will depend on the origin of the primary material used. The waste used to carry out the test has a lower heat value of $18^{\prime} 837 \mathrm{~kJ} / \mathrm{kg}$ and its composition is shown in Table I where the high proportion of plastic is enhanced;

\begin{tabular}{|c|c|c|c|}
\hline \multicolumn{2}{|c|}{$\begin{array}{c}\text { Proximate Analysis } \\
\text { (\%weight) }\end{array}$} & \multicolumn{2}{c|}{$\begin{array}{c}\text { Ultimate analysis } \\
\text { (\%weight) }\end{array}$} \\
\hline Humidity & 20.00 & Polyethylene & 96.80 \\
\hline Volatile material & 95.30 & Cellulose & 2.00 \\
\hline Fixed carbon & 4.50 & Wood & 1.00 \\
\hline Inert & 0.20 & Inert & 0.20 \\
\hline
\end{tabular}

Table I. - Paper Industry Waste composition

The refusal obtained by a gasification process is transformed essentially in a syngas (after the thermochemical process - element 3 of Fig. 1) with a composition reported in Table II, experimentally obtained by chemical analysis.

\begin{tabular}{|c|c|c|c|c|c|}
\hline Syngas & \multicolumn{2}{|c|}{ \%volume } & \multicolumn{2}{|c|}{ \%weight } & \multirow[t]{2}{*}{$\alpha_{s t}$} \\
\hline & wb & $\mathrm{db}$ & wb & db & \\
\hline $\mathrm{CH}_{4}$ & 8.41 & 6.69 & 5.350 & 11.70 & 17.16 \\
\hline $\mathrm{C}_{3} \mathrm{H}_{6}$ & 0.713 & 1.486 & 1.189 & 0.99 & 14.72 \\
\hline $\mathrm{C}_{3} \mathrm{H}_{8}$ & 0.136 & 0.299 & 0.239 & 0.19 & 15.61 \\
\hline $\mathrm{C}_{4} \mathrm{H}_{6}$ & $\mathbf{0 . 0 7 8 7}$ & 0.212 & 0.169 & $\mathbf{0 . 1 1}$ & 14.00 \\
\hline $\mathrm{C}_{5} \mathrm{H}_{6}$ & 0.0603 & 0.198 & 0.158 & 0.084 & 13.54 \\
\hline $\mathbf{O}_{2}$ & 0.576 & 0.913 & 0.730 & 0.80 & - \\
\hline CO & 5.69 & 7.89 & 6.313 & 7.90 & 2.46 \\
\hline $\mathrm{CO}_{2}$ & 5.61 & 12.24 & 9.79 & 7.80 & - \\
\hline $\mathbf{H}_{2}$ & 0.305 & 0.028 & 0.0022 & 0.40 & 34.15 \\
\hline $\mathbf{N}_{2}$ & 50.41 & 70.03 & 56.02 & 70.1 & - \\
\hline $\mathrm{H}_{2} \mathrm{O}$ & 28.0 & - & 20.0 & - & - \\
\hline \multicolumn{3}{|c|}{$\mathbf{H}_{\mathbf{i}}$} & \multicolumn{3}{|c|}{$3445 \mathrm{~kJ} / \mathrm{kg}$} \\
\hline \multicolumn{3}{|c|}{$T_{\text {syg }}$} & \multicolumn{3}{|c|}{$755^{\circ} \mathrm{C}$} \\
\hline \multicolumn{3}{|c|}{$\alpha_{\text {syg }}$} & \multicolumn{3}{|c|}{1.63} \\
\hline
\end{tabular}

The gas, released from the gasifier, is sent directly into the Syngas Combustion Chamber (element 5 of Fig. 1), without cooling, that's why the tar contained in the syngas is burned with.

\section{Mass and energy balances}

In order to perform the mass and energy balances relative to the Plant, the system has been schematized into three blocks: the first represents the natural gas combustion chamber used to produce the inert gases; the second schematizes the gasifier and the third represents the syngas and tar combustion chamber.

The first scheme (Fig. 2) is relative to the mass balances, while the second (Fig. 3) to the energy balances.

As well known, the gasification-pyrolysis process leads to the split of the input waste into three components called syngas, tar and char [7].

The stoichiometric air/fuel ratio values of tar and char reported in the literature $[7,8]$ it varies between $6-12$ and depends on the composition of the waste. Some properties of these are reported in the table III. 


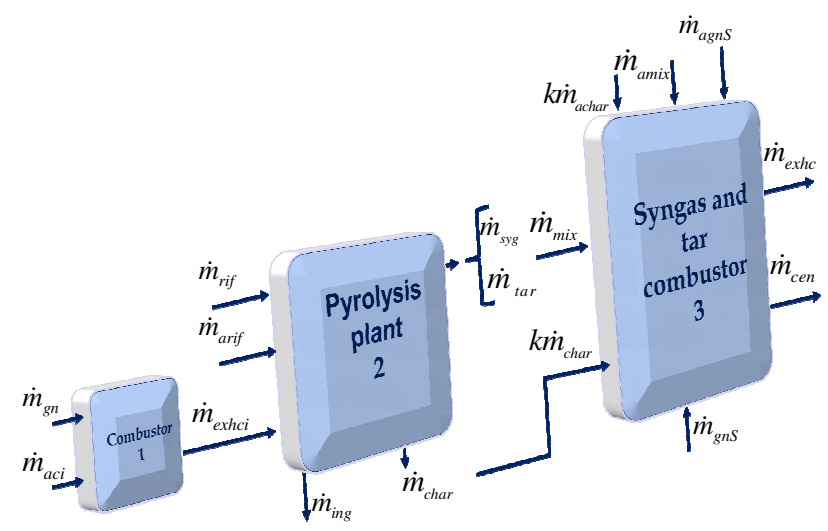

Fig. 2. Mass balance scheme

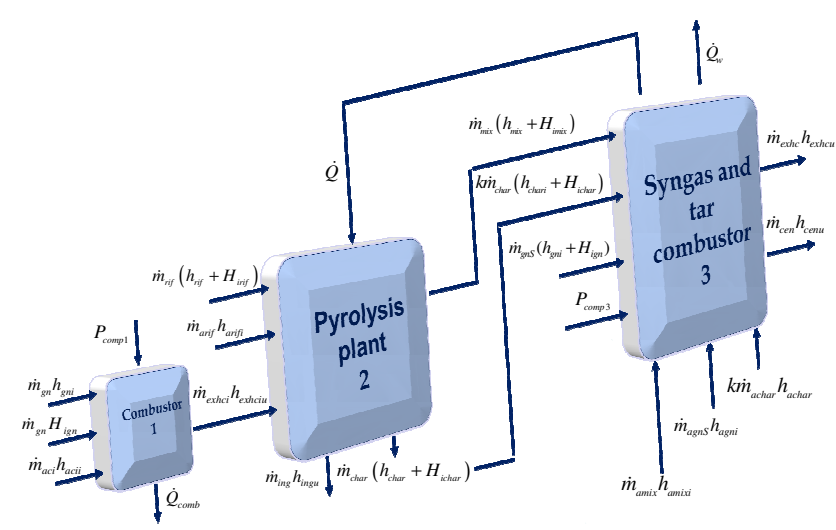

Fig. 3. Energy balance scheme

\begin{tabular}{|l|l|l|l|}
\hline & Tar & Char & Syngas \\
\hline $\mathrm{Hi}, \mathrm{kJ} / \mathrm{kg}$ & 5274 & 7535 & 3445 \\
\hline \% weight & $41.5 \%$ & $4.5 \%$ & $54 \%$ \\
\hline \multicolumn{4}{|c|}{ Table III. - Tar and Char proprieties }
\end{tabular}

Stoichiometric Air-Fuel ratio used in the present case to close the balance equations are 11.2 for the tar and 10 for char. These values has been confirmed by thermochemical analysis.

Tar and char stoichiometric air-fuel ratio and LHV values has been used to calculate the properties of the syngas and tar mixture (Tab.IV) obtained from the gasifier and then burned in the combustor.

\begin{tabular}{|c|c|}
\hline Hi & $4239.97 \mathrm{~kJ} / \mathrm{kg}$ \\
\hline$\alpha_{\text {st }}$ & 5.79 \\
\hline
\end{tabular}

Table IV. - Syngas and Tar Mixture properties.

\section{Thermodynamic model}

A thermodynamic and chemical simulation is realized with a commercial software [9-11] and a scheme (Fig. 1) is validated by experimental data confirming quantities values derived indirectly from mass and energy balances:

- Gasification temperature;

- Syngas composition.

The tuning variables used are:

- Paper Industry Waste composition;

- Inlet air flow rate into the gasifier.

The inputs have been supplied as following:
- $\quad$ gasification process characteristics (Tab.V);

- waste flow rate (Tab.V) and composition (Tab.VI).

\begin{tabular}{|l|l|}
\hline Mass feed material & $23240 \mathrm{~kg}$ \\
\hline Gasification temperature & $500^{\circ} \mathrm{C}$ \\
\hline $\begin{array}{l}\text { Mass flow rate of natural gas for inert gas } \\
\text { burner }\end{array}$ & $55 \mathrm{~kg} / \mathrm{h}$ \\
\hline Air index of inert gas burner & 1.15 \\
\hline Pressure of inert gas burner & $0.90 \mathrm{~atm}$ \\
\hline $\begin{array}{l}\text { Thermal power dispersed by the external } \\
\text { walls of the inert gas burner }\end{array}$ & $461.1 \mathrm{~kW}$ \\
\hline Internal pressure of gasifier & $0.80 \mathrm{~atm}$ \\
\hline $\begin{array}{l}\text { Mass flow rate of natural gas for syngas } \\
\text { burner }\end{array}$ & $185 \mathrm{~kg} / \mathrm{h}$ \\
\hline Air index of syngas burner & 1.88 \\
\hline Internal pressure of syngas burner & $0.70 \mathrm{~atm}$ \\
\hline $\begin{array}{l}\text { Thermal power dispersed by the external } \\
\text { walls of the syngas burner }\end{array}$ & $736.51 \mathrm{~kW}$ \\
\hline $\begin{array}{l}\text { Inlet air flow rate into the Paper Industry } \\
\text { Waste }\end{array}$ & $176.54 \mathrm{~kg} / \mathrm{h}$ \\
\hline
\end{tabular}

Table V. - Experimental data test

Starting from a literature Paper Industry Waste composition (Table VI), its value has been iteratively varied until the produced syngas composition is equal to the experimental data (Table VII).

\begin{tabular}{|c|c|c|}
\hline $\begin{array}{c}\text { Paper Industry } \\
\text { Waste composition }\end{array}$ & $\begin{array}{c}\text { Simulated } \\
\text { mass fraction }\end{array}$ & $\begin{array}{c}\text { Literature mass } \\
\text { fraction }[12,13]\end{array}$ \\
\hline $\mathrm{O} 2$ & 0.07 & $0.068-0.274$ \\
\hline $\mathrm{N} 2$ & 0.15 & $0.002-0.164$ \\
\hline $\mathrm{H} 2$ & 0.04 & $0.034-0.064$ \\
\hline $\mathrm{C}$ & 0.355 & $0.332-0.475$ \\
\hline $\mathrm{S}$ & 0.095 & $0.093-0.14$ \\
\hline Ashes & 0.01 & $0.01-0.114$ \\
\hline $\mathrm{H} 2 \mathrm{O}$ & 0.28 & $0.07-0.33$ \\
\hline
\end{tabular}

Table VI. - Experimental and numerical Paper Industry Waste composition Comparison.

\begin{tabular}{|c|c|c|c|}
\hline $\begin{array}{l}\text { Syngas } \\
\text { composition }\end{array}$ & $\begin{array}{l}\text { Simul. mass } \\
\text { fraction }\end{array}$ & $\begin{array}{l}\text { Experimental } \\
\text { mass fraction }\end{array}$ & Variation\% \\
\hline $\mathrm{CH}_{4}$ & 0,05297 & 0,053898 & $-1,72$ \\
\hline $\mathrm{C}_{3} \mathrm{H}_{6}$ & 0,01165 & 0,01189 & $-2,02$ \\
\hline $\mathrm{C}_{3} \mathrm{H}_{8}$ & 0,00243 & 0,00239 & $+1,67$ \\
\hline $\mathrm{C}_{4} \mathrm{H}_{6}$ & 0,00165 & 0,00169 & $-2,37$ \\
\hline $\mathrm{C}_{5} \mathrm{H}_{6}$ & 0,00161 & 0,00158 & $+1,90$ \\
\hline $\mathrm{O}_{2}$ & 0,00737 & 0,00730 & $+0,959$ \\
\hline $\mathrm{CO}$ & 0,06365 & 0,06313 & $+0,824$ \\
\hline $\mathrm{CO}_{2}$ & 0,0963 & 0,0979 & $-1,63$ \\
\hline $\mathrm{N}_{2}$ & 0,5681 & 0,5602 & $+1,41$ \\
\hline $\mathrm{H}_{2}$ & 0,00002262 & 0,000022 & $+2,82$ \\
\hline $\mathrm{H}_{2} \mathrm{O}$ & 0,1942 & 0,20 & $-2,90$ \\
\hline \multicolumn{2}{|c|}{ Mass flow rate } & $1414.81 \mathrm{~kg} / \mathrm{h}$ \\
\hline Stoichiometric ratio & \multicolumn{2}{|c|}{1.34} \\
\hline \multicolumn{2}{|c|}{ L.H.V. } & $3583.1 \mathrm{~kJ} / \mathrm{kg}$ \\
\hline
\end{tabular}

Table VII. - Experimental and numerical syngas composition Comparison. 
The simulation has also provided a Paper Industry Waste lower heat value equal to $19332.5 \mathrm{~kJ} / \mathrm{kg}$. The gasification temperature (average value inside the gasification reactor) supplied by numerical analysis are in agreement with the data provided by the experimental test. The Table VII shows the comparison between the syngas obtained from the simulation and the experimental tests:

To evaluate the electric energy potential produced by the gasifier, the Gassification Plant has been numerically coupled to a Biomass Steam Power Plant (BSPP), which characteristics (Table VIII) are experimentally and numerically analyzed in the paper [14], at which authors refer to deepen its distinctiveness. It has been supposed to introduce the gassifier plant exhaust flue gas (exactly from position 6 of Fig.1) in the steam generator of the Biomass Power Plant to exploit the residual enthalpy at relative high temperature (about $900{ }^{\circ} \mathrm{C}$ ). To remain at the nominal condition, it's necessary to feed that Power Plant [14] with 3 gassifier systems: the Net electric power generated is $2368 \mathrm{~kW}$ and the global electric efficiency, considering as fuel the waste $\left(\dot{m}_{\text {Waste }}\right)$ and the Natural Gas $\left(\dot{m}_{N G}\right)$ introduced in the Gassification Plant, is evaluated as following:

$$
\eta_{e l 1}=\frac{P_{e, n e t t a}}{3 \cdot \dot{m}_{\text {Waste }} \cdot H_{i-\text { Waste }}+3 \cdot \dot{m}_{N G} \cdot H_{i-N G}}=0.055
$$

A small size Power Plant could be an Organic Rankine Cycle Plant [15].

\begin{tabular}{|l|c|}
\hline Biomass mass flow rate & $2498 \mathrm{~kg} / \mathrm{h}$ \\
\hline Gross electric power & $2688 \mathrm{kWe}$ \\
\hline Electric power for auxiliary & $320 \mathrm{kWe}$ \\
\hline Net electric power & $2368 \mathrm{kWe}$ \\
\hline Electric efficiency & $23 \%$ \\
\hline \multicolumn{2}{|c|}{ Table VIII. - BSPP characteristics at Nominal Point in the } \\
Standard Configuration [14].
\end{tabular}

Another possible layout is a connection of only one Gassification Plant to a biomass steam turbine power plant as in Fig. 4; so to leave the BSPP at the nominal point is necessary to introduce also a reduced mass flow rate of the biomass (Table VIII).

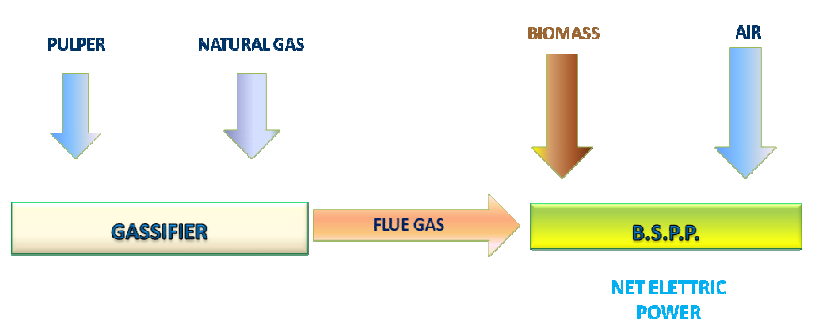

Fig. 4. Gasifier-BSPP layout.

In this type of connection, has been kept constant the design point of the steam cycle and such the electrical power generated, while the input biomass mass flow rate has been reduced to $1481 \mathrm{~kg} / \mathrm{h}$ (reduction of $40.7 \%$ ).

Evaluating the electrical efficiency as the following ratio:

$$
\eta_{e l 2}=\frac{P_{e, \text { netta }}}{\dot{m}_{\text {Waste }} \cdot H_{i-\text { Waste }}+\dot{m}_{N G} \cdot H_{i-N G}+\dot{m}_{\text {biomass }} \cdot H_{i-\text { biomass }}}
$$

a value of 0.155 has been obtained.

This result may appear low but it's necessary to consider that the flue gas leaving the gassifier plant was produced essentially by the waste. So, if it is considered the ratio excluding the Paper Industry Waste:

$\eta_{e l 2}^{*}=\frac{P_{e, \text { netta }}}{\dot{m}_{N G} \cdot H_{i-N G}+\dot{m}_{\text {biomass }} \cdot H_{\text {i-biomass }}}$

the value is of 0.262 ( 3 per cent points more than the standard value 0.23 reported in the Table VII).

Another possible layout could be to use the gasification system for very wet biomass.

In this case the system would be totally fueled with Renewable Energies.

\section{Conclusion}

Syngas composition obtained from the residuals in general, provides a low value of LHV. In this case, study the syngas composition gives an ultra low value of LHV. In this way, the gas is unusable to produce electrical energy with any type of engine. The results of this paper show that insufflating the natural gas with the pulper, the gasification begins. The heather provided by the combustion of the syngas, stands up the oxidation reaction providing the steady condition to produce a constant flow rate of syngas. In this way it is possible to have an interesting heather source. In this paper it has been analyzed that the heather provided from this technology, can be used to have several configuration of integrated power plant.

It is possible to use the heather produced by the gasification of the waste to reduce the mass flow rate of the biomass inside the traditional Biomass Combustion Steam Power Plant.

Furthermore, if the waste to oxidize has a high value of humidity, like some agricultural waste or humid residual civil waste, it is possible to exploit the remaining biomass LHV in a Gassification Plant as showed in the present paper. Using the oxygen contained inside the water of the humidity, it can increase the gasification reaction inside the waste, so it's possible to realize a total Renewable Energies Power Plant, exploiting high humidity biomass wastes too.

\section{References}

[1] Jinhu Wu, Yitain Fang, Yang Wang, "Production Of Syngas By Methane And CoalCo-Conversion In Fluidized Bed Reactor". Institute of Coal Chemistry, Chinese Academy of Sciences. P. O. Box 165, Taiyuan, 030001, People Republic of China.

[2] Jinhu Wu, Yitian Fang, Yang Wang, Dong-ke Zhang, "Combined Coal Gasification and Methane Reforming for Production of Syngas in a Fluidized-Bed Reactor". Energy \& Fuels 2005, vol. 19, pp. 512-516. 
[3] A. Calabrò, F. Samela, C. Bassano, P. Deiana "Analisi di un impianto sperimentale per la co-produzione di energia elettrica e di idrogeno da carbone con "quasi" zero emission di anidride carbonica", Report Ricerca Sistema Elettrico Aprile 2009.

[4] R. Hogg, "Energy from Waste by Pyrolysis and Gasification the Experience and Performance of an Operational Plant", Proceedings of the International Conference on Sustainable Solid Waste Management, 5 - 7 September 2007, Chennai, India. pp.385-392.

[5] Tae-HeonKwak,Seungmoon Lee, Jin-Won Park, SanjeevMaken, Young Done Yoo and Sang-Houck Lee "Gasification of municipal solid waste in a pilot plant and its impact on environment" Korean J. Chem. Eng., 23(6), 954-960 (2006).

[6] J.Fitzgerald "Waste Treatment Infrastructure Requirements for Municipal Solid Waste and Commercial/Industrial Waste in England 2010 - 2020".Thesis submitted Imperial College London.

[7] A. Demirbas, "Biomass resource facilities and biomass conversion processing for fuels and chemicals", Energy Conversion and Management, Trabzon 2001.

[8] S. Colantoni, A. Corradetti, U. Desideri, F. Fantozzi, "Thermodynamic analysis and possible applications of the integrated pyrolysis fuel cell plant (IPFCP)", ASME Turbo Expo 2007, GT2007-27713.

[9] Aspen Plus, User Guide version 10.2.

[10] Aspen Plus, Unit Operation Models version 10.

[11] Aspen Plus, Physical Property, Methods and models version 10.2

[12] Minutillo M., Maratta L., Jannelli E., "Analisi delle Prestazioni Energetiche ed Ambientali di Soluzioni Innovative per lo Smaltimento di Reflui Civili e Industriali", Atti $61^{\circ}$ Congresso Nazionale ATI - Perugia 12-15 Settembre 2006.

[13] M.C. Monte*, E. Fuente, A. Blanco and C. Negro , "Waste management from pulp and paper production in the european union", Chemical Engineering Department. Complutense University of Madrid. Avda. Complutense, s/n. 28040 Madrid (Spain)

[14] A. Gimelli, A. Luongo, "2.3 MW Biomass Steam Power Plant: Experimental and Thermodynamic Analysis", Accepted at the International Conference on Renewable Energies and Power Quality (ICREPQ'12). Santiago de Compostela (Spain), 28th to 30th March, 2012. Candidate for the Renewable Energies and Power Quality Journal (REPQJ), ISSN: 2172-038X.

[15] T.C. Hung, T.Y. Shai, S.K. Wang, "A review of organic rankine cycles (ORCs) for the recovery of low-grade waste heat”, Energy, Volume 22, Issue 7, July 1997, Pages 661667.

[16] J. Wu, P. Brown, I.Diakunchak, A.Gulati, M.Lenze, B.Coestlin Fuel "Advanced Gas Turbine Combustion System Development System For Hugh Hydrogen"Proceedings of GT2007 ASME Turbo Expo 2007: Power for Land, Sea and Air Proceedings of GT2007 May 14-17,

[17] De Stefanis P. (2001), Le tecnologie innovative per il recupero di energia dai rifiuti, Rapporto tecnico ENEA RT $A M B / 2001 / 25$. 